\title{
NUTRITION AND PUBLIC HYGIENE AMONG CHILDREN UNDER FIVE YEARS OF AGE IN MUKURU SLUMS OF MAKADARA DIVISION, NAIROBI
}

\author{
M.A. MUOKI, D.S. TUMUTI and G.O. ROMBO
}

\begin{abstract}
Objective: To determine the relationship between sanitation and malnutrition among children below five years.

Design: A random sampling followed by an experimental design on microbiological analysis of food and water samples.

Setting: Mukuru slums of Makadara division in Nairobi City.

Subjects: Eighty food and thirty water samples from households within the study area were used.

Results: Poor food and personal hygiene were observed within the households in the study area. Most of the respondents did not practice hygienic methods during food handling such as washing hands and vegetables before preparation. Food especially the leftovers was served at ambient temperatures. Sneezing and coughing over food during preparation were also a common practice which exposed consumers to contamination, Garbage disposal and proper drainage were also poor deepening on the sanitation problem. Microbiological analysis of water and food revealed that food and water quality were poor due to the high coliform counts and confirmed presence of Escherichia coli (E-coli) and Salmonella spp. pathogens which are known causes of diarrhoea in children under five years of age.

Conclusion: Poor hygienic and unsanitary practices are major causes of diarrhoea, hence malnutrition in crowded Mukuru slums of Nairobi City.
\end{abstract}

\section{INTRODUCTION}

Urbanisation rates in sub-Saharan Africa are very high. While the annual population growth rate was estimated to be $2.8 \%$ between 1980 and 1997, the proportion living in urban areas in the same region increased from 19\% in 1970 to 32\% in 1997 (1). In Kenya, the population growth rate between 1980 and 1997 was 3,4\% annually, while the proportion of the population living in urban areas increased from $10 \%$ in 1970 to 30\% in 1997 and that most of these new settlers moved into the already crowded slums $(1,2)$. The rate is fastest in Africa where urban population is expected to be more that double from 294 million in the year 2000 to 742 million by the year 2030, and most of these will be slum dwellers $(2,3)$.

Poor planning coupled with great influx of people has resulted in large informal settlements also known as slums in Nairobi and other urban centres in Kenya. The scenario has led to congestion 
in the study area. The informal settlements are characterised by high population densities, poor housing structures, lack of basic services such as water, sanitation and health facilities (2,4-6).

As a result of the growing number of urban dwellers within the slums, many are living below the poverty line of Kshs. 1,254 per month $(7,8)$. Poverty excludes people from benefits of healthcare systems. Diseases related to the unsanitary living environments, lack of water, childbirth problems and illnesses such as diarrhoea, vomiting, typhoid, worm infections, common colds, coughs and malaria are often mentioned in most environmental health surveys (4). Dietary intake and diarrhoeal disease incidences are potential sources of malnutrition.

Infant mortality rate (IMR) in Nairobi's informal settlement estimated at 91 per 1000 annually, is higher than in any other part of Kenya (4). Data indicate that only $44 \%$ of slum children aged between 12-23 months are fully vaccinated compared to $65 \%$ nationally, and that children under five are over 2.5 times more likely to die in the slums of Nairobi compared to the rest of the divisions within Nairobi City $(9,10)$.

The population data supplied by the Nairobi Water Supply Company show that the population has risen from 65,000 in 1940 to over two million people today (4). To access safe and adequate water in the slums is a serious problem. Informal settlements do not have piped water and residents have to walk long distances to fetch water from vendors or kiosks whose hygienic standards are equally questionable $(9,11)$. In addition to insufficient water supply, there have been numerous complaints that the Nairobi City Council does not treat the water it supplies to the residents to the required WHO standards raising fears about the spread of water borne diseases such as typhoid and cholera (10). Figure 1 summarises the causes and consequences of malnutrition in society.

Figure 1

Causes and consequences of malnutrition in society

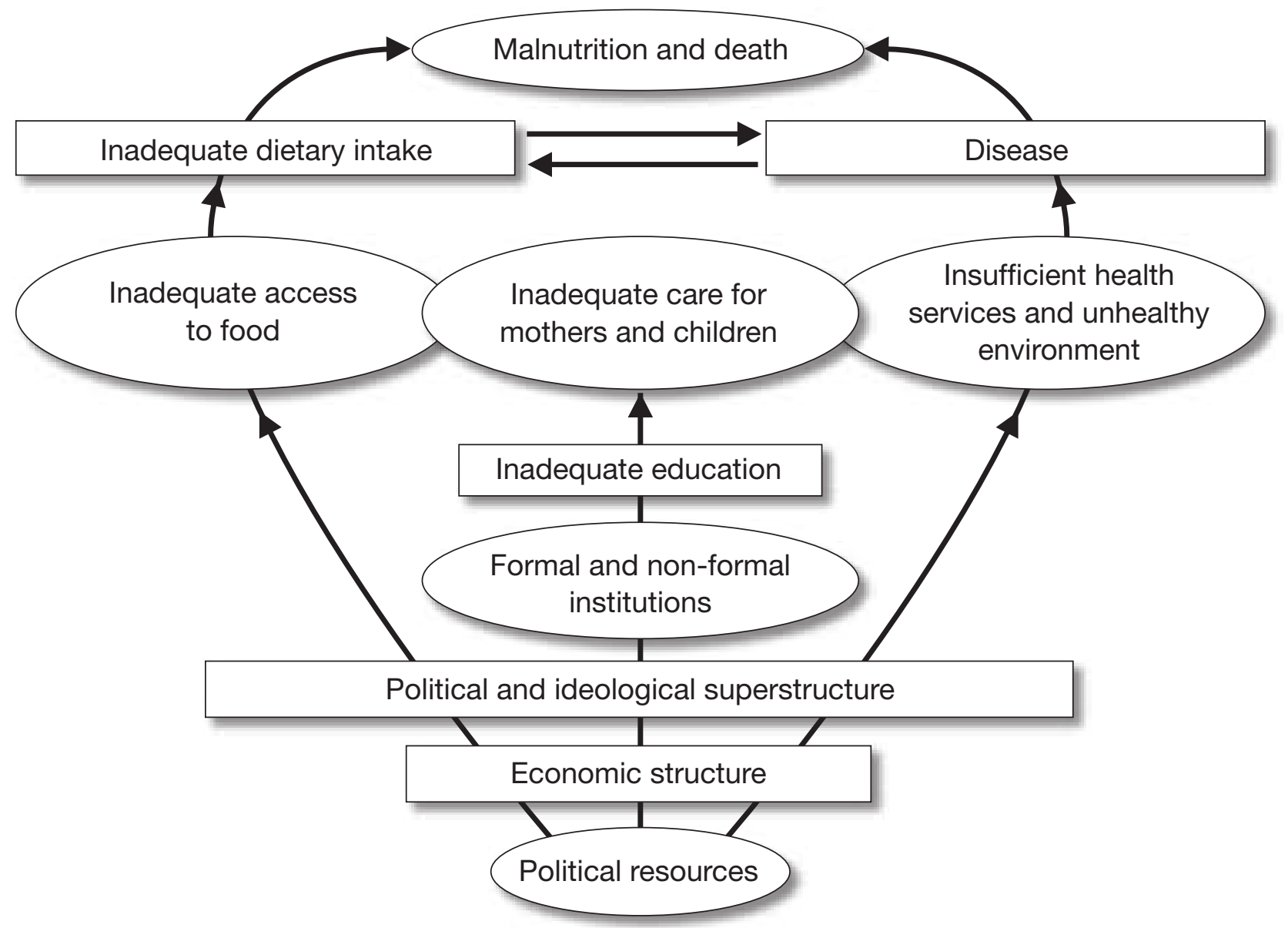

Source: UNICEF, Strategy for Improved Nutrition of Children and Women in Developing Countries, New York, UNICEF, 1990 (9) 
The Nairobi sewerage system is inadequate. Existing facilities are unable to cope with the needs of informal settlements where pit latrines serve an average of ten families and are usually submerged in water during rainy seasons. Further, the researcher observed in April 2007 that the existing sewerage system is poorly managed resulting in breakages, blockages and intentional piercing by unscrupulous people to obtain raw sewage water for irrigation. These factors may cause contamination of food and drinking water especially in the slums. Systematic reviews show that better water supply and improved sanitation are associated with decreased diarrhoea, morbidity, improved nutritional status and lower child mortality (12-14).

The physical environment in Mukuru slums is characterised by improper garbage and human waste disposal causing foul smells and filth. The uncollected piles of rubbish are good breeding grounds for rodents, mosquitoes, flies and other pests. People scavenge for food while children play with the garbage creating more health and disease problems.

This study was carried out in Mukuru slum, one of the largest and poorest in Nairobi. It is found in Makadara division. The division has a population of approximately 184,541 people. The poverty incidences of individuals below poverty line at $59 \%$, which is highest compared to other divisions in Nairobi. The population is mainly made up of males and females informally employed, such as food vendors, sellers of second hand clothes and shoes, "kiosks", shopkeepers and charcoal; others work in nearby industries and the Jua Kali (hotsun) sector. Few people work in the formal sector such as the civil service, teaching and private companies.

\section{MATERIALS AND METHODS}

An experimental design on microbiological analysis of food and water in the study area was done in 80 households. The study was carried out in Mukuru slum, Makadara Division, Nairobi. Mukuru slum is about five kilometres from the city centre to the south and is bordered on both sides by South " $\mathrm{B}$ ' estate and industrial area. It is a fast growing informal settlement with population estimated at 100,000 (personal communication, Millicent, Assistant chief, Mukuru Location)

Mukuru slum is in Mukuru Nyayo Location which has two sub-locations; Hazina and Nairobi south. Hazina sub-location was randomly selected for the study. Hazina has three villages namely Hazina, Kisii and Maasai. The target groups were children below five years. Mukuru slum has no system of waste disposal. Household waste is disposed of in piles near houses while human waste is disposed of as "flying toilets" in paper bags and plastic tins onto the roads, nearby rivers and garbage site. Interestingly, food safety at household and community level has received very little attention especially in slum neighbourhoods. Water contamination and poor hygiene are certainly major sources of disease. It is also possible that poor people may have no alternative to purchasing and consuming food unfit for human consumption (15-18).

Microbiological analysis of food and water: Food and water samples were collected, from Mukuru slum residents, in $500 \mathrm{ml}$ sample bottles and were then refrigerated. Analysis was done within five hours. A total of 80 food and 30 water samples were analysed. All tests were done in triplicates after serial dilutions to $10^{-6}$. Solid food samples were collected refrigerated at $5^{\circ} \mathrm{C}$. A portion of 25 grams was homogenised in $225 \mathrm{ml}$ buffered peptone water and serial dilutions made from original to $10^{6}$.

Total aerobic plate count: The total viable aerobic count was done using plate count agar (PAC) (Hi media Ltd, Bombay). According to AOAC method, 966.23 (19) the agar was kept in water baths at $45-50^{\circ} \mathrm{C}$ to avoid solidification before pouring. Aliquots of $0.1 \mathrm{ml}$ of appropriate dilutions were spread on to pre-dried PCA agar using sterile glass rods. The inoculated dishes were then inverted and incubated at $37^{\circ} \mathrm{C}$ for 48 hours.

Confirmatory tests for coliforms: Brilliant Green Lactose Bile Broth (2\%) (Oxoid Ltd, Basing Stoke, England) was reconstituted and dispensed into fermentation tubes, incorporated with inverted Durham tubes in $5 \mathrm{~m} 1$ quantities and sterilised for 15 minutes at $121^{\circ} \mathrm{C}$ and allowed to cool to room temperature. The broth culture from the positive presumptive tests were used to inoculate $2 \%$ brilliant green lactose broth and incubated at $37^{\circ} \mathrm{C}$ for 48 hours. Production of gas confirmed the presence of coliforms in the original sample.

Confirmation of salmonella organisms in food and water samples: The salmonella spp. in water and food 
samples were first resuscitated (regimented) by the method described by Harigan (1998). An aliquot of $25 \mathrm{ml}$ or a gram of sample was added to $225 \mathrm{ml}$ of lactose broth and incubated at $37^{\circ} \mathrm{C}$ for 18 hours.
Samples of $0.1 \mathrm{ml}$ of various dilutions were then spread on Bismuth sulphate agar BSA (Hi media Ltd, Bombay and incubated at $37^{\circ} \mathrm{C}$ for 24 hours.

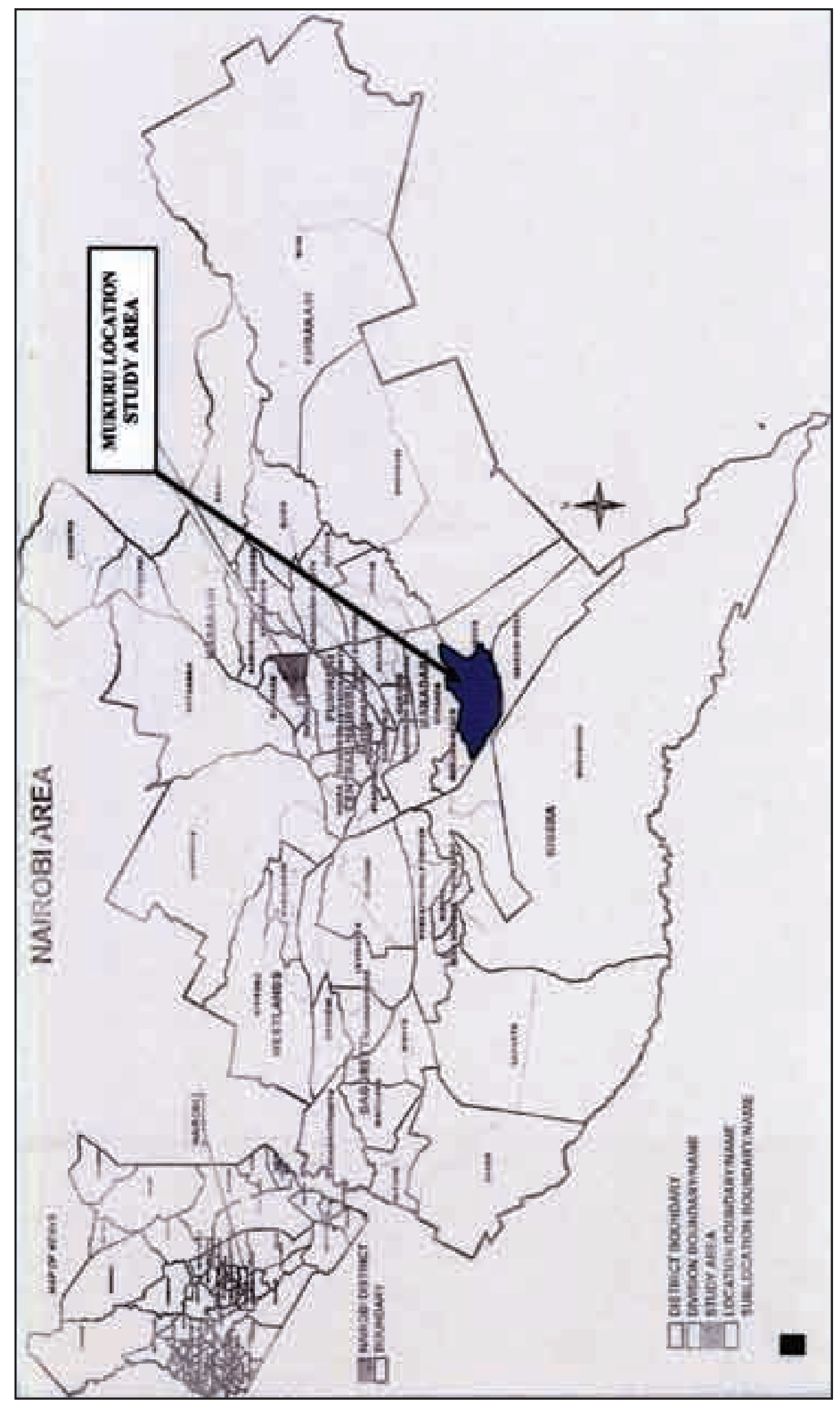




\section{RESULTS}

The aim of this study was to assess hygienic and sanitary practices within the households in order to establish the microbiological safety of food and water consumed by the respondents. The study looked at practices such as cooking and handling of food, water supply, personal and environmental hygiene. Proper sanitation can reduce food contamination and waterborne diseases that causes illness.

Food hygiene entails steps being taken to ensure that all conditions and necessary measures for safety and suitability of food at all stages of the food chain are implemented. Food hygiene is concerned with the study of the causes and prevention of the illness associated with consuming contaminated foods. Proper handling and preparation of food greatly reduce the risk of transmitting food borne illness such as diarrhoea especially among children (18).

Table 1 indicates that $51.2 \%$ of the respondents bought their food from street vendors close to their houses while $11.3 \%$ bought food from the market. Food from vendors was preferred because it was ready to eat and affordable to the respondents $(19,20)$. However, the dangers that go with eating these foods are costly (21). Results further show that most of the respondents $(47.5 \%)$ did not wash vegetables before cooking. The vegetables were mostly pre-cut and packed in polythene papers ready for sale. Such vegetables are preferred because they save time and labour in preparation. Acquisition of raw and un-inspected food is a contributing factor to food borne diseases $(19,21)$. Results in Table 1 also show that most respondents $(60.0 \%)$ served warm food. This was done to save fuel. Food was cooked in the morning and kept warm ready to eat. Ambient temperature is conducive for the growth of microorganisms and is one of the common causes of food poisoning.

Twenty five per cent of respondents did not use clean utensils for food preparation and serving (Table 1). The table also shows that most of the respondents $(91.3 \%)$ reused leftovers while only $8.7 \%$ discarded them. Leftovers should be stored either hot $\left(60^{\circ} \mathrm{C}\right.$ and above or at cool temperatures below $\left.5^{\circ} \mathrm{C}\right)$ to avoid contamination $(8,20)$.
Table 1

Food hygiene practices

\begin{tabular}{lll}
\hline Variable & No. & $(\%)$ \\
\hline Source of food & & \\
Street vendor & 41 & 51.2 \\
Kiosks & 30 & 37.5 \\
Market & 9 & 11.3 \\
\hline Total & 80 & 100 \\
\hline
\end{tabular}

Washed vegetables before

cooking

\begin{tabular}{lll} 
Yes & 26 & 32.5 \\
Sometimes & 16 & 20.0 \\
No & 38 & 47.5 \\
\hline Total & 80 & 100 \\
\hline
\end{tabular}

Food temperature

\begin{tabular}{lll} 
Hot & 14 & 17.5 \\
Warm & 48 & 60.0 \\
Cold & 18 & 22.5 \\
\hline Total & 80 & 100 \\
\hline
\end{tabular}

Clean utensils

$\begin{array}{lll}\text { Yes } & 45 & 56.3\end{array}$

$\begin{array}{lll}\text { No } & 20 & 25.0\end{array}$

$\begin{array}{lll}\text { Sometimes } & 15 & 18.7\end{array}$

Total $\quad 80 \quad 100$

Handling of left over food

\begin{tabular}{lll} 
Used for next meal & 73 & 91.3 \\
Throw away & 7 & 8.7 \\
\hline Total & 80 & 100 \\
\hline
\end{tabular}

Personal hygiene: Personal hygiene is an important aspect of food preparation and service because human beings are the largest source of food contamination (11). The study sought to find out whether respondents observed personal hygiene such as handling food after washing hands, sneezing and coughing over food during handling and wearing protective clothes.

Most of the respondents (47.5\%) did not wash hands when handling food. Dirty hands and sores contribute to food contamination (Table 2). At household levels, proper hand washing after using toilets and before handling food can help prevent food borne diseases, such as typhoid $(22,23)$. 
Most of the respondents did not use handkerchiefs while handling food hence they sneezed or coughed over food during preparation $(77.5 \%)$. These practices are known to contaminate food $(24,25)$. Food handlers with cold or flu like symptoms may also contaminate food. Results in table 2 also show that most of the respondents did not wear protective clothes during food preparation (93.8\%) (Table 2).

Results in table 2 also indicate that $27.5 \%$ of respondents had long nails while $17.5 \%$ had polished nails. Long nails harbour dirt which can contaminate food $(26,27)$.

Table 2

Personal hygiene

\begin{tabular}{lll}
\hline Variable & No. & $(\%)$ \\
\hline Condition of hands when & & \\
handling food & & \\
$\quad$ Washed hands & 32 & 40.0 \\
$\quad$ Did not wash hands & 38 & 47.5 \\
$\quad$ Unprotected sores & 10 & 12.5 \\
\hline Total & 80 & 100 \\
Sneezing/coughing over food & & \\
during preparation & 18 & 22.5 \\
$\quad$ Used handkerchief & 62 & 77.5 \\
$\quad$ Did not use handkerchief & 80 & 100 \\
\hline Total & & \\
\hline Nails & 22 & 27.5 \\
$\quad$ Long & 44 & 55.0 \\
Short & 14 & 17.5 \\
$\quad$ Polished & 80 & 100 \\
\hline Total &
\end{tabular}

Environmental hygiene: Informal settlements are characterised by high population densities, poor housing, lack of basic services such as water, toilets, stagnant water or poor drainage, piles of rotting garbage which attract rodents, flies and other pests leading to unhealthy environmental and poor sanitation. Sanitation actually relates to physical, chemical, biological and microbial principles of food environment and health. Systematic review shows that better sanitation is associated with decreased diarrhoea, infant morbidity, improved nutritional status and lower childhood mortality.

Most respondents $(53.7 \%)$ did not have any drainage facility (Table 2). Dirty water from the houses was poured outside. Stagnant water was a common feature during rainy seasons, posing health hazards due to breeding of mosquitoes, which transmit malaria.

Most of the respondents (60\%) only swept the floor of their houses and did not mop them with water because most floors were earthen and water was scarce most of the time. This was more hazardous to the health of young children than adults (Table 2). Most of the respondents ( $55 \%$ ) used the "flying toilets" where human waste was disposed into polythene bags and thrown everywhere including garbage dumps, nearby river or near the houses. Only $(12.5 \%)$ used toilets, which were not enough due to congestion. The results further show that most of the respondents $(42.5 \%)$ disposed of their garbage very near to their homes and only (2.5\%) burned it (Table 3).

Table 3

Environmental hygiene of respondents

\begin{tabular}{lll}
\hline Variable & No. & $(\%)$ \\
\hline Garbage disposal & 34 & 42.5 \\
Near the home & 12 & 15.0 \\
Garbage dump & 32 & 40.0 \\
Nearby river & 2 & 2.5 \\
Burning & 80 & 100 \\
\hline Total & & \\
\hline Human waste disposal & 10 & 12.5 \\
Toilet & 25 & 32.5 \\
Garbage dump & 43 & 55.0 \\
Flying toilet & 80 & 100 \\
\hline Total & & \\
Drainage & 12 & 15.0 \\
Fair & 25 & 31.3 \\
Poor & 43 & 53.7 \\
$\quad$ None & 80 & 100 \\
\hline Total & & \\
\hline House cleanliness & 48 & 60.0 \\
Swept floor with water & 20 & 25.0 \\
Mopped floor with water & 12 & 15.0 \\
Cleaned outside the house & 80 & 100 \\
\hline Total & & \\
\hline
\end{tabular}

Microbiological food quality analysis: A total of 80 samples were taken from foods, which were most 
frequently consumed daily within the households. All food samples were contaminated with coliforms. Maize/beans samples showed the highest mean of $3.6 \times 10^{3}$ coliform counts. E-coli were present in all foods at varying degrees and salmonella also tested positive in maize/ugali and tea/milk (Table 4). Ecoli being gastrointestinal were transmitted through faeces and secretions, which in turn contaminated air and water supplies $(28,29)$.

The kiosks and houses where foods were stored and prepared also served as habitats for rats, cockroaches and flies.

Water quality: Water is essential for supporting human health, but also potential for transmitting a wide variety of diseases including pathogenic bacteria, viruses, worms and protozoa $(25,29)$. The study analysed water samples from taps and water stored in containers. The water is supplied by the Nairobi City Council through a vast network of intertwining pipes made of either metal or plastic. Thirty samples of water were obtained from the three villages in Mukuru slums.
The Kenya Bureau of Standards (KBS) recommendations of 1996, stipulates that any water for human consumption must not contain more than three coliforms per $100 \mathrm{ml}$, and none should be of faecal origin $(24,29)$. Recent developments in sterilising drinking water have seen the use of ultra-violent (UV) radiation. UV radiation acts by attacking the largest molecules in bacteria, the DNA molecules of its nucleus; hence its replication is blocked. Bacterial cells with denatured DNA can not reproduce any more (30).

Three stand pipe water sources were contaminated with coliforms (10). The sources were from all the three villages, Kisii having the highest $(30 \%)$ compared to Maasai $(10 \%)$. Salmonella was positive in two villages, Kisii and Hazina.

Table 7 indicates that $40.6 \%$ out of 160 children were stunted. Stunting was the most prevalent form of malnutrition. It is a measure of linear growth where one is too short for their age. It reveals longterm distress on both food and non-food hence it reflects the cumulative effect of chronic malnutrition, $(12,22,33)$.

Table 4

Bacterial counts in the sampled food items

\begin{tabular}{|c|c|c|c|c|}
\hline Type of food & TPC CFU / gm & Coliform per 1gm (CFU/gm) & E-Coli (CFU/gm) & Salmonella \\
\hline \multicolumn{5}{|c|}{ Maize/Ugali (n=15) } \\
\hline Mean & $1.7 \times 10^{4}$ & $2.5 \times 10^{3}$ & $1.5 \times 10^{2}$ & $20.4 \%$ were \\
\hline Range & $\left(2.5 \times 10^{2}-2.8 \times 10^{4}\right)$ & $\left(1.7 \times 10^{3}-2.0 \times 10^{4}\right)$ & $1.8 \times 10^{2}-2.3 \times 10^{3}$ & positive \\
\hline \multicolumn{5}{|c|}{ Maize/beans $(n=15)$} \\
\hline Mean & $8.1 \times 10^{3}$ & $3.6 \times 10^{3}$ & $2.2 \times 10^{3}$ & $0 \%$ \\
\hline Range & $5.2 \times 10^{2}-6.0 \times 10^{3}$ & $2.5 \times 10^{2}-3.5 \times 10^{3}$ & $2.5 \times 10^{3}-3.5 \times 10^{4}$ & \\
\hline \multicolumn{5}{|c|}{ Maize porridge $(\mathrm{n}=15)$} \\
\hline Mean & $4.7 \times 10^{3}$ & $2.7 \times 10^{2}$ & $1.2 \times 10^{2}$ & $35.2 \%$ were \\
\hline Range & $3.5 \times 10^{1}-2.2 \times 10^{3}$ & $1.5 \times 10^{2}-1.2 \times 10^{3}$ & $1.2 \times 10-2.0 \times 10^{3}$ & positive \\
\hline \multicolumn{5}{|c|}{ Mandazi / chapati $(n=15)$} \\
\hline Mean & $4.7 \times 10^{2}$ & $3.7 \times 10^{2}$ & $1.7 \times 10^{2}$ & $16.5 \%$ were \\
\hline Range & $3.5 \times 10^{1}-2.2 \times 10^{3}$ & $1.8 \times 10^{1}-1.2 \times 10^{3}$ & $1.2 \times 10^{2}-2.0 \times 10^{4}$ & positive \\
\hline \multicolumn{5}{|c|}{ Beef / chicken stew $(n=10)$} \\
\hline Mean & $2.6 \times 10^{2}$ & $4.1 \times 10^{2}$ & $1.7 \times 102$ & $31.6 \%$ were \\
\hline Range & $1.8 \times 10-32.6 \times 10^{3}$ & $2.0 \times 10-2.4 \times 10^{3}$ & $2.2 \times 10^{2}-6.0 \times 10^{3}$ & positive \\
\hline \multicolumn{5}{|c|}{ Vegetable salads $(\mathrm{n}=10)$} \\
\hline Mean & $2.6 \times 10^{2}$ & $2.1 \times 10^{2}$ & $1.2 \times 10^{2}$ & $0 \%$ \\
\hline Range & $1.8 \times 10-4.3 \times 10^{2}$ & $3.2 \times 10-6.0 \times 10^{2}$ & $1.5 \times 10^{1}-2.2 \times 10^{2}$ & \\
\hline
\end{tabular}


Table 5

Bacterial counts in water samples from stand pipes serving Mukuru Nyayo households

\begin{tabular}{|c|c|c|c|c|c|c|}
\hline \multirow[t]{3}{*}{ Village } & \multirow[t]{3}{*}{ Sample size } & \multirow[t]{3}{*}{ Mean TBC } & \multirow[t]{3}{*}{ Mean MPN } & \multicolumn{3}{|c|}{ Proportions positive } \\
\hline & & & & \multicolumn{2}{|c|}{ E-coli } & \multirow[t]{2}{*}{ Salmonella } \\
\hline & & & & No. & $(\%)$ & \\
\hline Maasai & 10 & 200 & 28 & 1 & 40 & $0 \%$ \\
\hline Kisii & 10 & 280 & 56 & 3 & 30 & $38 \%$ \\
\hline Hazina & 10 & 250 & 42 & 2 & 20 & $25 \%$ \\
\hline
\end{tabular}

Table 6

WHO guideline values for bacteriological quality of drinking water (31)

\begin{tabular}{ll}
\hline Organism & Guideline value \\
\hline All water intended for drinking & \\
E. coli or thermotolerant coliform bacteria & Must not be detectable in any $100 \mathrm{ml}$ sample \\
Treated water entering distribution system & \\
E. coli or thermotolerant Coliform bacteria & Must not be detectable in any $100 \mathrm{ml} \mathrm{sample}$ \\
Total coliform bacteria & Must not be detectable in any $100 \mathrm{ml}$ sample \\
Treated water in the distribution system & \\
E. coli or thermotolerant Coliform bacteria & Must not be detectable in any $100 \mathrm{ml}$ sample \\
Total coliform bacteria & Must not be detectable in any $100 \mathrm{ml} \mathrm{sample}$ \\
\hline
\end{tabular}

Table 7

Prevalence of malnutrition among children below five years in Mukuru Nyayo in percentage $(n=160)$

\begin{tabular}{lccc}
\hline Form of malnutrition & Total/global $(\leq 2 \mathrm{SD})$ & Moderate -2 SD to $-3 S D$ & Severe $-3 S D$ \\
\hline Stunting (height/age) & 40.6 & 25.0 & 15.6 \\
Wasting (weight/height) & 13.3 & 9.4 & 3.9 \\
Underweight (weight/age) & 30.5 & 18.8 & 11.7 \\
\hline
\end{tabular}

Table 8

Significance difference tests using Chi-square test

\begin{tabular}{llllll}
\hline & $\begin{array}{l}\text { Nutritional } \\
\text { status }\end{array}$ & $\begin{array}{l}\text { Maize/Ugali/ } \\
\text { Porridge: } \\
\text { Salmonella }\end{array}$ & $\begin{array}{l}\text { Maize beans: } \\
\text { Salmonella }\end{array}$ & $\begin{array}{l}\text { Mandazi } \\
\text { Chapati: } \\
\text { Salmonella }\end{array}$ & $\begin{array}{l}\text { Beef/chicken } \\
\text { stew/vegetable } \\
\text { salads Salmonella }\end{array}$ \\
\hline Chi-square $(\mathrm{a}, \mathrm{b}, \mathrm{c})$ & 11.732 & 5.400 & 1.667 & 8.067 & 1.600 \\
Df & 2 & 1 & 1 & 1 & 1 \\
Asymp. Sig. & .003 & .020 & .197 & .005 & .206 \\
\hline
\end{tabular}

a 0 cells $(0 \%)$ have expected frequencies less than 5 . The minimum expected cell frequency is 27.3 .

b 0 cells $(0 \%)$ have expected frequencies less than 5 . The minimum expected cell frequency is 7.5. c 0 cells $(0 \%)$ have expected frequencies less than 5 . The minimum expected cell frequency is 5.0. 
The table also shows that $13.3 \%$ out of 160 children were wasted. Wasting is a condition reflecting acute malnutrition. The child is too thin for its height. It is a result of inadequate food intake, incorrect feeding practices and ill health. It also indicates short-term deprivation and describes current nutritional status $(11,20,33)$.

Table 7 further indicates that $30.5 \%$ out of 160 children were underweight. Underweight is mainly a consequence of inadequate diet and frequent infection leading to deficiencies in calories, proteins, vitamins and minerals. Such children receive nutrients below the required dietary allowance (RDA's) $(22,33)$.

Using chi-square tests, it was established that, there is a significant difference between the dietary intake and bacterial counts more specifically Salmonella. This test was done at both 95\% (0.05) and $99 \%$ (0.01) confidence interval. Comparing the asymptotic significance levels and the confidence interval levels, it was established that (0.02) is less than (0.05) implying that maize/ugali/porridge has significance in relation to salmonella count. The study indicated that there are significant differences in salmonella incidence and mandazi or chapati intake at $\mathrm{p} \leq 0.05$.

Personal and environmental hygiene: Coefficent of determination of personal hygiene and environmental hygiene are $R^{2}(0.9,0.72)$ respectively. This implies that $90 \%$ variations in the dependent variable are explained by personal hygiene such as source of food, among others. This is greater than that of environmental hygiene, where $72 \%$ variations in the dependent variable are attributable to environmental practices such as disposal of waste among others.

Using Analysis of variance (ANOVA), it was determined that there is a very high correlation between morbidity of children and microbial counts in food and water samples from Mukuru slums. Similar findings were reported in the Machakos study of Alexander Muller and Jeroen van Ginneken on morbidity and mortality in Machakos, Kenya (1974 -1981) though the location was rural while in this study, Mukuru slums was in an urban setting (33). Other studies in sub-Saharan Africa found that unclean domestic environment, lack of toilets and lack of piped water were related to the risk of diarrhoea leading to chronic malnutrition (35).

Figure 2

Relationship between nutritional status and hygienic practices of children under 5 years

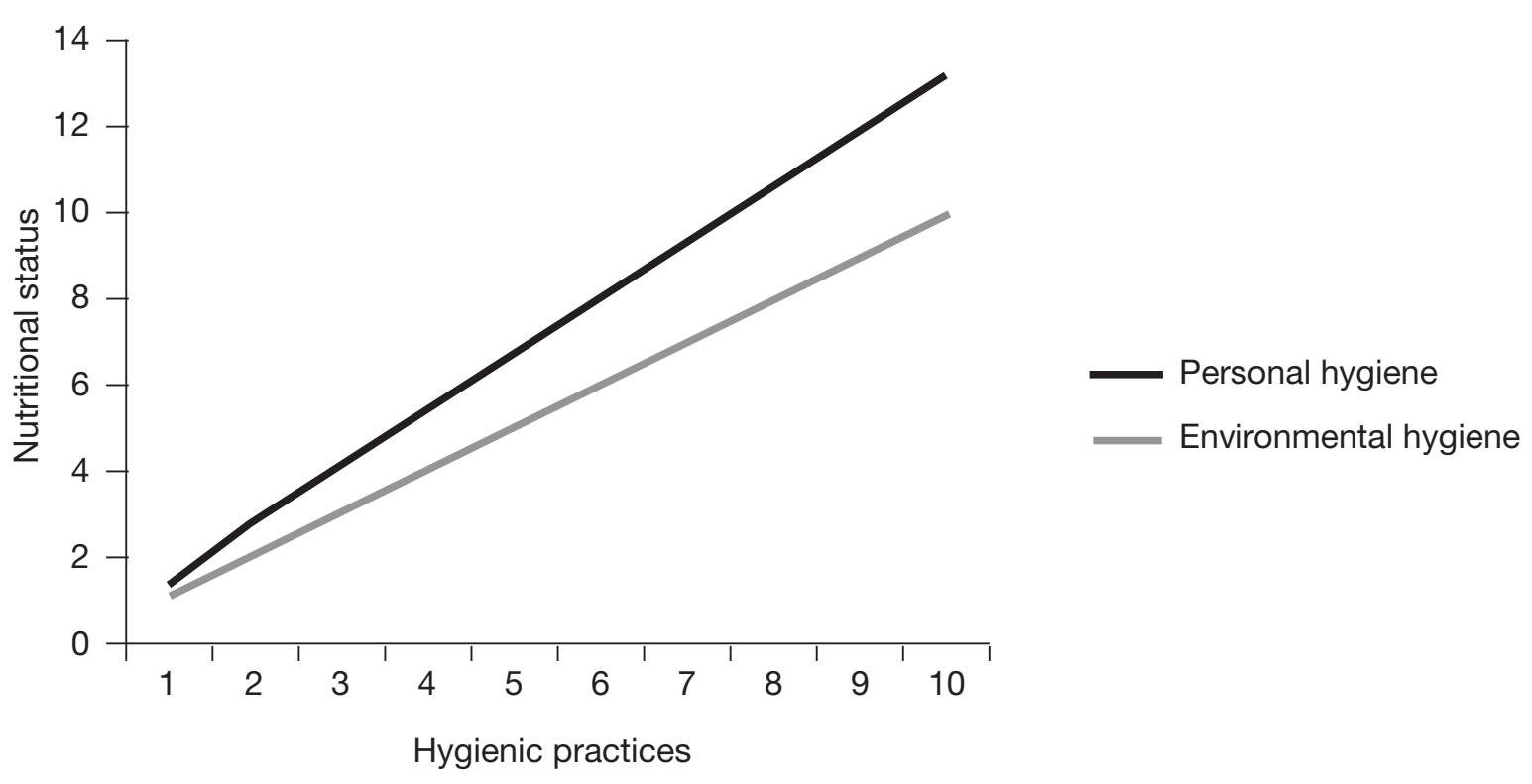




\section{DISCUSSION}

Sanitation means formulation and application of measures to promote quality of public health (1992). One of the most common causes of child morbidity and mortality in developing countries is diarrhoea $(32,35)$. However, the presence of microorganisms in human food by itself may not imply direct infection to consumers. It has been established that the microbial load must reach some minimum threshold before disease symptoms can show in consumers. It is reported that at least $10^{2} \mathrm{CFU}$ of most salmonella species per $\mathrm{ml}$ (or per gm) is necessary to cause disease in consumers, both young and old (32).

Microbiological qualities of foods and water consumed in crowded slums are very similar to those of street foods consumed in the same areas. They are purchased from the same sources, stored in similar premises, prepared by the same people in dusty environments and sold and consumed under completely similar conditions (35). However, studies in Minia - Egypt, Manikganj - Bangladesh and Iloilo, Philippines, indicated that street foods are as safe as or safer than foods prepared in homes of most customers $(35,36)$. Some authors reason that sanitary conditions in many poor urban homes (believed to be the main consumers of street foods) are little different from those of street food vendors, and neither vendors nor buyers will perceive any problems with street food or water hygiene (37).

Lack of basic sanitation, like in the unfavourable conditions that exist in slums of cities in many developing countries, can lead to food contamination at home or in the street kiosks $(36,37)$. A study comparing microbiological quality or traditional street foods with home-prepared and tourist hotel foods revealed that although some street foods were heavily contaminated, the microbiological quality of some of the foods was comparable to those prepared at home and tourist hotels (37). Other studies on slum foods also reveal that not all foods are unsafe $(36,38)$. In addition, there appears to exist no convincing evidence that street foods are more implicated in the transmission of infection and intoxication than foods obtained elsewhere. However, there is generally incomplete notification of food borne infections in developing countries (38). Nevertheless, if a community is to have full benefits of the street vended foods, they should have minimal risk of food borne disease. Hence intervention is required to ensure that the standard of safety for such food is the best attainable in the context of the prevailing local situation $(38,39)$. Food hygiene practices such as washing hands before handling food, washing vegetables before cooking and serving warm or hot food and use of dirty utensils were not observed. Respondents also preferred to buy food from street vendors, but the danger that goes with eating these foods are higher and costly in terms of the health of the consumers. Personal hygiene of respondents especially during food handling was not keenly observed and most of them did not use handkerchiefs when sneezing or coughing hence causing more risks to food contamination.

In conclusion, although some piped water reaches water "kiosks" in Mukuru, the high microbial load noted in some domestic water sources could be due to contamination in the corroded pipes as was also observed in other urban water supplies by Chemuliti $(40,41)$. Systematic reviews show that better sanitation is associated with decreased morbidity, improved nutritional status and lower childhood mortality $(41,42)$.

Malnutrition among children below five years in slum areas is influenced by many different factors in which sanitation is prevalent. The prevalence which includes diarrhoeal diseases can result in poor growth through decreased absorption of nutrients and increased requirements thereby contributing to general protein energy malnutrition. Improved sanitation in the slum areas should therefore be central to all initiatives geared towards improvement of the health and nutritional status of children.

The health and livelihood conditions of slum dwellers are diverse. The dwellers suffer from poverty, poor access to safe food and adequate drinking water, and poor sanitary facilities which pre-dispose them to illness.

We recommend that programmes geared at improving the welfare of children should concurrently address issues related to promotion of good health through immunisation in hospitals free of charge. Information about public health should be up to date, accurate and in the public domain and should be improved by involving qualified medical staff. This remark applies to both public health and NGOs, Nairobi City Council, faith-based groups, government interventions and women groups. 


\section{ACKNOWLEDGEMENTS}

To the area chief and respondents of Mukuru Location for their cooperation during data collection. Special thanks go to Mr Francis Obongo of KIRDI for microbiological analysis and advice on food and water samples, Dr. Peter Gathura, Public Health Department, Kabete Campus for advice and analysis of food and water samples, Mr. Henry Kimani of Nairobi City Council for advice, KEMRI, AMREF, NEMA, UNICEF, UNIDO and libraries within Nairobi for their support and access to information.

\section{REFERENCES}

1. World Bank. World Development Indicators. World Bank, Washington, DC, 1999.

2. Habitat (United Nations Centre for Human Settlement). An Urbanizing World: Global Report on Human Settlement: Oxford University Press, London, 1996.

3. African Population and Health Centre (APHRC) Health and Livelihood needs of residents of informal settlements in Nairobi City. Nairobi African Population and Health Centre. 2002; 1-13.

4. Environment Liaison Centre International - ELCI Community guide to environmental issues and to go to the environmental management and coordination Act. of 1999. ELCI, 2002.

5. Ashworth, A. and Dowler, E. Child malnutrition. In: Disease and mortality in sub-Saharan Africa. R. G. Feachem and Jamison, D. T. (eds.). World Bank, Washington, DC. 1991; 122-133.

6. Government of Kenya. Housing and population census Vol. 1; Government Printer Nairobi. 2000; 1-5.

7. Geda, A., de Jong, N. Mwabu, G. and Kimenyi, MS. Determinants ofpoverty in Kenya. Household level Analysis. The Kenya Institute for Public Policy Research and Analysis, KIPRA, Nairobi, 2001

8. Young, B. and Briscoe, 1. A case control study of the effect of environmental sanitation on diarrhoea morbidity in Malawi. J. Epidemiol. Comm. Health. 1988; 42: 83-88.

9. UNICEF, Strategy for improved Nutrition of Children and Women in Developing Countries, New York, UNICEF, 1990.

10. NCSS (Nairobi Cross-Sectional Slums Survey), (http:// www.aphrc.org)info@aphrc.org, 2007.

11. Esrey, S.A. Feachem, R.G. and Hughes, J.M. Interventions for control of diarrhoeal diseases among young children; Improving water supplies and excreta disposal facilities. Bull. WHO. 1985; 63: 757-722.

12. Esrey, S.A. and Habicht, J.P. The impact of improved water supplies and excreta disposal facilities of diarrhoea morbidity, growth and mortality among children. In: A methodology to review public health interventions; results from nutritio-supplements and water sanitation projects. SA. Esrey. J.P. Habitch, and W.P. Butz (eds) Cornell International Nutrition Monograph Series No. 15 Cornell University, Ithaca; 1985.

13. Esrey, S.A., Potash, J.B., Roberts, L. and Shiff, C. Effects of improved water supply and sanitation on ascaris, diarrhoea, dracunculiasis, hookworm infection, schistosomiasis and trachoma. Bull. WHO. 1991; 69: 609-621.

14. Government of Kenya $2^{\text {nd }}$ Report on Poverty Vol. 1; Incidence and depth of Poverty. Government Printer. Nairobi 2005; 1-22.

15. Henry, F.J., Alam, N., Aziz, K.M. and Rahaman, M.M. Dysentry not watery diarrhoea, is associated with stunting in Bangladeshi children. Human nutrition and Clinical Nutrition. 1987; 41C: 243-249.

16. Kimenyi, MS. Agriculture, economic growth and poverty reduction. Kipra Occasional Paper No. 3. 2002.

17. Sen, A.K. Poverty and famines: An essay on entitlement and deprivation. Oxford University Press, London. 1983.

18. Martins, J.H. and Anelich, L.E. Socioeconomic features of street food vending hygiene and microbiological status of street foods in Gauteng. Report prepared for FAO Rome; 2000.

19. AOAC, Official methods of analysis of AOAC International, $16^{\text {th }}$ Edn. Methods 950,46,98,09,991,36,92 0,153,975,55,993,17,968,22. Washington DC 1995.

20. Stembera, Z. Prospects for higher infant survival. World Health Forum. 1990; 11: 78-80.

21. Ombui, J.N., Kagiko, MM. and Arimi, SM. Foodborne disease in Kenya. East Aft. Med. J. 2001; 78: 40-44.

22. World Health Organisation (WHO) Global Database on Child Growth and Malnutrition. WHO, Geneva, 2003.

23. Hedberg, C.W. Epidemiology of food Illness. In: Food microbiology. Fundamentals and frontiers ( $2^{\text {nd }}$ edn.) M.P. Doyle, L.R. Beuchat and T.J. Montiville (eds). Amer. Soc. Microbiol. Washington. 2007; 435-447.

24. Gathura, P.B., Kyule, M.N., Kagiko, M.M., et al. Water supply and quality control Kenya. The past, present and future. The Kenya Veterinarian. 2002; 23: 33-34.

25. Viessman, Jr., W. and Hammer, M.J. Water Supply and Pollution Control. ( $6^{\text {th }}$ edn.). Madison Wesley Longman, London. 1996. 
26. Bryan, F.L, Jermini, M., Semit, R., et al. Nutritional, hygienic and socioeconomic dimensions of street foods in urban areas. The case of Nairobi, PhD Thesis, University of Wageningen; 2002.

27. Borgdorf, M.W. and Motaijemi, Y. Surveillance of food borne diseases: What are the options?, WHO, Geneva, 1997; 26.

28. Oliver, J.D and Kaper, J.B. Vibrio species. In: Food microbiology fundamental and frontiers. Edn. M.P. Doyle, L.R. Beuchat and T.J. Monteville (eds). Amer. Soc. Microbiol. Washington, DC. 2001; 263-300.

29. D' Aust, J.Y, Maurer J. and Bailey, J.S. Salmonella species. In: Food microbiology fundamental and frontiers. 2 d Ed. M.P. Doyle, L.R. Beuchat and T.J. Monteville (eds). Amer. Soc. Microbiol. Washington, DC. 2001; 141-178.

30. Rombo, G.O. Physico-chemical effects of irradiation on starch and proteins of maize and bean flours. PhD Thesis, University of Pretoria, South Africa; 2002.

31. WHO. Guidelines for drinking water quality ( $\left.2^{\text {nd }} e d n.\right)$. Volume 3: surveillance and control of community water supplies. WHO, Geneva, 1997.

32. WHO. Research on improved infant feeding practices to prevent diarrhoea or reduce its severity: Memorandum from a JHUIWHO meeting. Bull. WHO. 1989; 28: 27-32.

33. Muller, AS. and van Ginneken, J.K. Morbidity and Mortality in Machakos, Kenya, 1974-81. Oxford University Press. 1991.
34. Kirkwood, B.R. Diarrhoea. Oxford University Press. 1991.

35. Gopalan, C. Nutrition in developmental transition in South East Asia. New Delhi WHO Regional Office for South East Asia, 1992.

36. Draper, A. Street foods in developing countries: The potential for micronutrient fortification. London Sch. Trop. Med. 1996.

37 Lunven, P. Feeding cities: a challenge for the future. Archivos Latinoamericanos de Nutricion 1994; 44: 89-101.

38. ILSI. Streetfoods: Epidemiology, management and practical approaches. Beijing, China, ILSI Abstracts, Washington DC., October 19-21, 1993.

39. WHO. Essential safety requirements for street vended foods. WHO, Geneva, 1996.

40. Chemuliti, J.K. Assessment of bacteriological quality of drinking water in Kibera sub-location, Nairobi City, Kenya. MVPH Thesis, Nairobi University, Kenya, 1999.

41 Pelletier, D.L., Frongillo, Jr. E.A., Schroeder, D.G. and Habitch, P. The effects of malnutrition on child mortality in developing countries. Bull. WHO. 1995; 73: 443-448.

42. Smith, L.C. and Haddad, L. Overcoming child malnutrition in developing countries: Past achievements and future choices. Int. Food Policy Res. Inst. Discussion paper. 2000; 30: 4-6. 